\title{
KEKOHESIAN WACANA STAND UP COMEDY DI KOMPAS TV
}

\author{
Zumrotul Ilmiyah \\ Guru Madrasah Tsanawiyah Negeri (MTsN) Lamongan \\ Telp. 082337545488 \\ Pos-el zumrotulilmiyah7@gmail.com
}

\begin{abstract}
Abstrak: Penelitian ini bertujuan menghasilkan deskripsi tentang kekohesian wacana stand up comedy (Dodit Mulyanto) di Kompas TV. Jenis penelitian ini adalah penelitian deskriptif kualitatif. Objek penelitian yang diangkat dalam penelitian ini yaitu penandapenanda kohesi dalam wacana stand up comedy (Dodit Mulyanto) di Kompas TV.Teknik yang digunakan dalam pengumpulan data penelitian ini yaitu teknik simak, teknik SBLC (Simak Bebas Libat Cakap), teknik rekam, teknik catat, dan teknik transkripsi. Data yang diperoleh dianalisis secara deskriptif kualitatif. Hasil dari penelitian ini menunjukkan bahwa aspek kohesi sangat mendukung dalam membangun sebuah keutuhan wacana stand up comedy. Aspek kohesi yang ada dalam wacana stand up comedy mencakup kohesi gramatikal (Pronomina, substitusi, ellipsis, dan konjungsi), dan kohesi leksikal (Antonim, hiponim, kolokasi, sinonim, dan repetisi). Adapun aspek kohesi gramatikal konjungsilah yang mendominasi dalam penelitian ini.
\end{abstract}

Kata kunci: stand up comedy, wacana, kohesi

\begin{abstract}
The research method in this research is descriptive qualitative. The research object is the cohesion discourse in Stand up Comedy performed by Dodit Mulyanto on Kompas TV. The technique used to collect the research data is by listening, SBLC, recording, noting, and taking transcription technique. The data then analyzed by using descriptive qualitative method. The result shows that the cohesion aspects give much contribution in improving the whole Stand up Comedy discourse. The cohesion aspect in Stand up Comedy are grammatical cohesion (Pronominal, substitution, ellipsis, and conjunction) and lexical cohesion (Antonym, hyponym, collocation, synonym, and repetition). However the aspect of grammatical conjunction much dominates in this research.
\end{abstract}

Keywords: stand up comedy, discourse, cohesion

\section{PENDAHULUAN}

Humor merupakan sebuah sarana hiburan yang menimbulkan kelucuan dan menyebabkan tawa bagi pendengar ataupun pemirsa. Melalui humor manusia dapat menghadapi ketimpangan masyarakat dengan canda tawa. Wacana humor yang menjadi bahan kajian tulisan ini adalah stand up comedy.

Stand up comedy merupakan sebuah bentuk pertunjukan seni komedi yang dibawakan secara monolog oleh 
seorang comic secara langsung di depan para penonton. Stand up comedy sesungguhnya merupakan label baru dalam seni melawak, khususnya seni lawak monolog.

Stand up comedy adalah lawakan yang lebih banyak mengandalkan kemampuan bahasa komika (pelaku stand up comedy) daripada gerakan tubuh. Komika berhumor dengan membawakan karakter bahasa masing-masing. Misalnya dengan mengombinasikan materi humor yang berhubungan dengan logat daerah asal komika, pengalaman, dan kehidupan sosial. Komika berusaha membuat penontot berusaha tertawa dengan permainan kata yang dapat mengundang respons tertawa. Permainan bahasa yang bersifat kompleks dapat memengaruhi perkembangan bahasa Indonesia. Menyusun materi lawakan tentu tidak lepas dari aspek-aspek kohesi agar terbentuk menjadi suatu materi lawakan yang koheren. Kohesi merupakan aspek yang berkenaan dengan hubungan bentuk antara bagian-bagian dalam suatu wacana. Selanjutnya, koherensi merupakan aspek yang menandai hubungan makna secara semantis antar bagian wacana. Jadi, jelaslah wacana yang baik haruslah mencerminkan faktor kohesi dan koherensi.

Chaer (1994:267) menjelaskan, bahwa wacana adalah satuan bahasa yang lengkap, sehingga dalam hirarki gramatikal merupakan satuan gramatikal yang tertinggi dan terbesar. Wacana dikatakan lengkap karena di dalamnya terdapat konsep, gagasan, pikiran, atau ide yang utuh, yang bisa dipahami oleh pembaca (dalam wacana tulis) atau oleh pendengar (dalam wacana lisan) tanpa keraguan apapun.

Berkaitan dengan wacana bahasa stand up comedy, penelitian ini memilih wacana lisan stand up comedy. Wacana lisan cenderung kurang terstruktur (gramatikal), penataan subordinatif lebih sedikit, jarang menggunakan piranti hubung (alat kohesi). Aspek yang akan dikaji dalam penelitian ini adalah mengenai penanda kohesi wacana stand up comedy di KOMPAS TV (Dodit Mulyanto).

Kohesi merupakan perkaitan antar proposisi yang dinyatakan secara eksplisit oleh unsur-unsur gramatikal dan semantik dalam kalimat-kalimat yang membentuk wacana (Alwi dkk, 2000:427).

Ghufron (2015:173) mengemukakan bahwa kohesi dalam wacana diartikan sebagai kepaduan bentuk secara struktural membentuk ikatan sintaktikal. Konsep kohesi pada dasarnya mengacu kepada hubungan bentuk. Artinya, unsurunsur wacana (kata atau kalimat) yang digunakan untuk menyusun suatu wacana memiliki keterkaitan secara padu dan utuh.

Kohesi terdiri atas lima jenis, yaitu referensi, substitusi, ellipsis, konjungsi, dan leksikal. Dasar dari pengklasifikasian itu ditemukan pada sistem leksikogramatika. Dengan demikian, kohesi sebagai sistem semantik, direalisasikan melalui sistem leksikogramatika. Walaupun kohesi direalisasikan melalui sistem leksikogramatika, hubungan kohesi itu adalah hubungan makna. Oleh karena itu kesenambungan yang diciptakan juga merupakan makna (Halliday dan Hasan, 1979: 303).

Berdasarkan paparan di atas, perlu adanya penelitian yang bertujuan untuk mendeskripsikan kekohesian wacana stand up comedy di Kompas TV.

\section{METODE PENELITIAN}

Penelitian ini dirancang dengan menggunakan kajian deskriptif kualitatif. Penelitian ini menggunakan pendekatan 
kualitatif karena data yang dihasilkan adalah berupa data deskriptif berupa katakata, kalimat tertulis atau lisan dan tidak mengandung makna numerik.

Data diperoleh melalui pengunduhan video di www. Youtube.com yang ada pada acara stand up comedy di Kompas TV 2014 yang kemudian ditranskip dalam bentu tulis. Semua data itu dijadikan sebagai sampel penelitian.

Untuk mengumpulkan data dalam penelitian ini digunakan teknik simak, catat, dan transkripsi. Teknik analisis data dengan mencari gambaran tentang penanda-penanda kepaduan (kohesi) dan keruntutan (koherensi) wacana stand up comedy yang telah ditentukan.

Prosedur analisis data dengan penglasifikasian data yang merupakan suatu metode analisis yang menggunakan tabel klasifikasi. Tabel ini untuk memilah-milahkan data berdasarkan rumusan masalah penelitian.

\section{HASIL PENELITIAN}

Hasil penelitian yang berjudul "Kekohesian Wacana Stand Up Comedy di KOMPAS TV" peneliti menemukan penanda kohesi yang terdapat dalam wacana stand up comedy.

Kekohesian yang terdapat dalam penelitian ini, pembahasan mengenai penanda kohesi terdiri dari aspek gramatikal sebanyak 37 wacana dan aspek leksikal sebanyak 11 wacana, penanda kohesi tersebut merupakan pembentuk kekohesian suatu wacana. Wacana Stand up Comedy yang telah dikaji dalam penelitian ini dari aspek gramatikal sebanyak 37 wacana tersebut dapat diklasifikasikan menjadi yaitu pertama, penanda kohesi pronomina yang terbagi lagi menjadi pronomina persona yang ditunjukkan oleh kata "saya", "kami", dan "kita" sebanyak 4 wacana, pronomina penunjuk yang berupa yang berupa "ini", "itu”, sebanyak 4 wacana,pronomina demonstrative waktu sebanyak 2 wacana, pronomina penanya yang berupa "dimana", "kenapa", dan "apa" sebanyak 2 wacana

Penanda kohesi aspek gramatikal yang berupa substitusi nominal sebanyak 2 wacana dan yang berupa subtitusi klausa sebanyak 1 wacana. Penanda kohesi aspek gramatikal yang berupa elipsis terdiri dari 3 wacana.

Penanda kohesi aspek gramatikal yang berupa konjungsi sebanyak 20 wacana, penanda konjungsi tersebut dapat dibedakan menjadi 4 bagian yaitu 1) konjungsi koordinatif sebanyak 4 wacana yang ditunjukkan dengan kata "dan","atau", "atau", "tetapi”, “, "padahal", 2) konjungsi korelatif sebanyak 2 wacana yang ditunjukkan dengan kata "dari ... hingga", "dari ... sampai"; 4) konjungsi subordinatif sebanyak 3 wacana yang ditunjukkan dengan kata "kalau"; 5) konjungsi antar kalimat sebanyak 10 wacana yang ditunjukkan dengan kata "kemudian", "kalau", dan "walaupun".

Dari uraian di atas bahwa penanda kohesi aspek gramatikal tersebut meliputi penanda pronomina, penanda substitusi, penanda elipsis, dan penanda konjungsi. Penanda-penanda kohesi tersebut merupakan pembentuk kekohesian wacana Stand up Comedy ini dapat ditemukan sebanyak 8 wacana.

Penanda kohesi yang dipakai atau yang digunakan untuk membentuk wacana Stand up Comedy di KOMPAS TV terdiri dari penanda kohesi aspek gramatikal yaitu (1) pronomina, (2) substitusi, (3) elipsis, (4) konjungsi, dan penanda kohesi aspek leksikal terdiri dari (1) antonim, (2) hiponim, (3) kolokasi, (4) sinonim, (5) repetisi.

Penanda kohesi antarkalimat yang sering muncul yaitu pronomina dan konjungsi. Sedangkan penanda substitusi, 
elipsis, antonim, sinonim, dan repetisi jarang muncul dalam penelitian ini. Berdasarkan deskripsi tersebut penulis menyimpulkan bahwa penanda kohesi yang efektif membentuk wacana Stand up Comedy di KOMPAS TV adalah penanda pronomina dan konjungsi.

\section{PEMBAHASAN}

Data yang dikumpulkan dari hasil penelitian terhadap sumber data dianalisis sesuai dengan rumusan masalah dan tujuan penelitian yang telah ditentukan. Pada bagian ini akan disajikan deskripsi hasil analisis data penelitian tentang kohesi dan koherensi wacana stand up comedy di KOMPAS TV. Penanda yang dipakai untuk menunjukkan kekohesian dalam wacana tersebut antara lain penanda kohesi aspek gramatikal yang meliputi pronomina, substitusi, elipsis dan konjungsi. Sedangkan untuk penanda kohesi aspek leksikal meliputi antonim, hiponim, kolokasi, sinonim, dan repetisi.

\section{Penanda Kohesi antarkalimat Aspek Gramatikal \\ Pronomina}

Pronomina adalah kata yang dipakai untuk mengacu kepada nomina lain. Ada tiga macam pronomina dalam bahasa Indonesia, yakni (a) pronomina persona, (b) pronomina penunjuk, (c) pronomina penanya (Alwi dkk, 1998:249).

Menurut Sumarlam (2003:24) jenis kohesi gramatikal pengacuan ini dapat diklasifikasikan menjadi tiga macam sebagaimana diuaraikan sebagai berikut. Pengacuan persona direalisasikan melalui pronomina persona (kata ganti orang), yang meliputi persona pertama, kedua, dan ketiga maupun jamak. Pengacuan demonstratif (kata ganti penunjuk) dapat dibedakan menjadi dua, yaitu pronomina demonstratif waktu (temporal) dan pronomina demonstratif tempat (lokasional). Pengacuan komparatif (perbandingan) ialah salah satu jenis kohesi gramatikal yang bersifat membandingkan dua hal atau lebih yang mempunyai kemiripan atau kesamaan dari segi bentuk/wujud, sikap, sifat, watak, perilaku, dan sebagainya.

Penggunaan penanda kohesi antarkalimat yang berupa pronomina atau yang biasa disebut kata ganti dalam penelitian ini hanya 3 bentuk, pronomina persona, pronomina penunjuk, dan pronomina penanya.

Penggunaan pronomina persona merupakan penanda kohesi yang dipakai untuk mengacu ke orang. Pronomina ini dapat mengacu pada diri sendiri (pronomina persona pertama tunggal) dan pronomina jamak, kemudian pronomina yang mengacu pada orang yang diajak bicara (pronomina persona kedua) tunggal maupun jamak, dan pronomina yang mengacu pada orang yang dibicarakan (pronomina persona ketiga) tunggal maupun jamak.

Berikut contoh penggunaan pronomina pertama tunggal "saya" sebagaimana kutipan berikut.

(1) "Selamat sore kawula muda, nama saya Dodit Mulyanto.Walaupun saya Jawa, keluarga saya itu memegang erat budaya Eropa makanya saya diajari main biola dari kecil. Cara menidurkan saya pun, beda sama bayi-bayi biasa. Kalau bayi biasa itu, kalau orang Jawa itu dinyanyikan "tak lelo lelo ledong juk menengo anakku cah bagus". Kalau saya itu beda, saya itu minimal "twinkletwinkle little star penekno blimbing kui”. (I/1/PR/2-4)

Penanda "saya" pada data (1) merupakan pronomina pertama tunggal, bentuknya adalah baku dan formal. Penanda pada data (1) tersebut menyampaikan maksud bahwa komika memperkenalkan jati dirinya kepada para pemirsa TV.

\section{Substitusi}

Substitusi ialah proses atau hasil penggantian unsur bahasa oleh unsur 
yang lain dalam satuan yang lebih besar untuk memeroleh unsur-unsur pembeda atau menjelaskan suatu struktur tertentu (Kridalaksana, 1984:185).

Ghufron

mengemukakan bahwa peranti kohesi substitusi (penggantian) adalah peranti yang menciptakan hubungan yang diwujudkan dengan mengambil "bentuk lain" untuk menggantikan satu bentuk linguistik yang diacu.

Penggunaan kohesi antarkalimat yang berupa substitusi pada penelitian ini ditunjukkan oleh penanda subtitusi sebagaimana dalam kutipan berikut.

(2)" Saya itu mengamati fashion murid-murid saya. Menurut saya kalau anak-anak itu dandanannya aneh-aneh itu tidak nakal tetapi hanya cari perhatian pada lawan jenisnya." (II/1/SB/7).

Penanda "anak-anak" pada data (2) merupakan hasil dari penggantian unsur nominal yang terdapat dalam kalimat sebelumnya atau sebagai penjelas yang mengacu pada kalimat "Saya itu mengamati fashion murid-murid saya." Penanda "murid-murid" mengalami subtitusi nominal diganti dengan penanda "anak-anak".

\section{Elipsis}

Elipsis ialah peniadaan kata atau satuan lain yang ujud asalnya dapat diramalkan dari konteks bahasa atau konteks luar bahasa (Kridalaksana, 1984:45). Peranti kohesi elipsis (pelesapan) adalah peranti yang menciptakan hubungan yang diwujudkan dengan mengambil bentuk "zero" untuk menggantikan bentuk linguistik yang diacu (Ghufron, 2015:174).

Penggunaan penanda kohesi antarkalimat yang berupa elipsis pada penelitian ini adalah sebagaimana dalam kutipan berikut.

(3)"Walaupun saya Jawa, keluarga saya itu memegang erat budaya Eropa, tentu saja saya memperhatikan fashion. Kalau saya ke hajatan wedding, saya itu minimal memakai toksedo.
Kemeja biasa, panuan saya! Tahu susunannya pakai toksedo?" Kemeja putih lengan panjang, pakai dasi, biasanya saya pakai merah ada tulisannya TUTWURI HANDAYANI, pakai ves pakai jas, singlet di luar biar gokil, kalau sudah gitu ya minimal saya naik mobil".(II/1/EL/17-19)

Penanda kohesi yang berupa elipsis pada data (3) memberikan maksud bahwa dalam kalimat tersebut terdapat peniadaan kata atau satuan yang ujud asalnya dapat dijelaskan dari konteks bahasa atau konteks luar bahasa. Peniadaan kata dari data tersebut yaitu yang terdapat dalam kalimat pada data (3).

\section{Konjungsi}

Konjungsi adalah salah satu jenis kohesi gramatikal yang dilakukan dengan cara menghubungkan unsur yang satu dengan unsur yang lain dalam wacana. Dilihat dari perilaku sintaksisnya dalam kalimat, konjungsi dibagi menjadi tiga kelompok: (1) konjungsi koordinatif, (2) konjungsi korelatif, (3) konjungsi subordinatif.

Penggunaan penanda kohesi antarkalimat yang berupa konjungsi pada data penelitian ini meliputi konjungsi koordinatif, konjungsi korelatif, konjungsi subordinatif, dan konjungsi antarkalimat.

\section{Konjungsi Koordinatif}

Penggunaan penanda kohesi yang berupa konjungsi koordinatif ditandai dengan kata “dan”,"atau”,"padahal”, "tetapi", sebagaimana dalam kutipan berikut.

(4)'Lingkungan hidup mempengaruhi seluruh aspek kehidupan manusia, dari seniman dipengaruhi karya-karya seniman dipengaruhi oleh lingkungan hidupnya. Gesang tinggal di lingkungannya, Bengawan Solo. Lagu yang dihasilkan lagu keroncong susah ya. Bengawan solo sudah. Gomblo lahir di Jombang, Jombang itu lingkungannya sawah dan pesantren." (V/1/K/16) 
Penggunaan penanda kohesi yang berupa konjungsi koordinatif dengan pemakaian kata "dan" pada data (4) merupakan konjungsi yang menghubungkan dua unsur kata yang sama pentingnya sebagai hubungan penambahan.

\section{Konjungsi Korelatif}

Penggunaan penanda kohesi yang berupa konjungsi korelatif ditandai dengan kata "dari...hingga....", "dari....sampai..."sebagaimana kutipan berikut.

(5)" Lingkungan hidup ada dua unsur, lingkungan hidup ada biotik dan abioik. Lingkungan abiotik adalah lingkungan bersih yang tidak hidup, terdiri dari air, tanah dan udara. Tapi, semua berubah sejak negara api menyerang. Unsur biotik adalah unsur hidup dari makhluk kecil tidak kasat mata hingga makhluk besar kasat mata. Artinya dari makhluk hidup mikrokokopis hingga makhluk hidup mikrokokopis gokil.”(V/1/K/10)

Penggunaan penanda kohesi yang berupa konjungsi korelatif pada (5) yang berupa kata atau frase "dari ... hingga ...." merupakan konjungsi korelatif. Penanda konjungsi korelatif yang berupa "dari ... hingga ...."pada data (5) dalam kalimat "Unsur biotik adalah unsur hidup dari makhluk kecil tidak kasat mata hingga makhluk besar kasat mata.

\section{Konjungsi Subordinatif}

Penggunaan penanda kohesi yang berupa konjungsi subordinatif ditandai dengan kata "kalau" sebagaimana kutipan berikut.

(6)" Walaupun saya Jawa keluarga saya itu memegang erat budaya eropa, tentu saja saya memperhatikan fashion. Kalau saya kehajatan wedding, saya itu minimal memakai toksedo, kemeja biasa panuan saya. Tahu susunannya pakai toksedo, kemeja putih lengan panjang, pakai dasi, biasanya saya pakai merah ada tulisannya TUTWURI HANDAYANI, pakai ves pakai jas, singlet di luar biar gokil, kalau sudah gitu ya minimal saya naik mobil."Naik motor kampungan, aturannya pun ya beda kalau naik angkot."(II/1/K/21)

Penggunaan penanda kohesi yang berupa konjungsi subordinatif pada data
(6) yang berupa kata "kalau" merupakan penanda konjungsi subordinatif syarat yang menghubungkan klausa " aturannya pun ya beda" dengan kalimat yang menjadi persayaratan dalam kalimat klausa tersebut yaitu pada kalimat "naik angkot".

\section{Konjungsi antarkalimat}

Penggunaan penanda kohesi yang berupa konjungsi antarkalimat ditandai dengan kata atau frase "kemudian", "kalau”, "walaupun", sebagaimana dalam kutipan berikut.

(7)" Kalau pacaran sama pemain biola itu enak. Kalau pacaran sama orang biasa itu, "sayang main tetanik-tetanik an yuk!", “ayuk!”. Kemudian, "ayuk kamu tangannya terlentang sayang", sreet.

Penggunaan penanda kohesi yang berupa konjungsi antarkalimat pada data (7) yang berupa kata atau frase "kemudian" yang menghubungkan kalimat "Kalau pacaran sama orang biasa itu, "sayang main tetanik-tetanik an yuk!", “ayuk!". Penanda konjungsi antarkalimat yang berupa kata "kemudian" dalam data (7) yaitu kalimat "Kemudian, "ayuk kamu tangannya terlentang sayang", sreet.", fungsi penanda "kemudian" dalam data (7) adalah menyatakan kelanjutan dari peristiwa atau keadaan pada kalimat sebelumnya dengan menggunakan alat penghubung berupa penanda konjungsi antarkalimat "kemudian" dihubungkan dengan kalimat sesudahnya.

\section{Aspek Leksikal}

Penggunaan penanda kohesi antarkalimat stand up comedy di KOMPAS TV dalam penelitian ini sebagai berikut.

\section{Antonim}

Antonim menurut Verhaar ialah ungkapan (biasanya berupa kata, tetapi dapat pula berbentuk frase atau kalimat) 
yang maknanya dianggap kebalikan dari makna ungkapan lain (Chaer, 1990:91).

Penggunaan penanda kohesi antarkalimat yang berupa antonim dalam penelitian ini ialah antonim yang bersifat relatif atau bergradasi, antonim yang bersifat mutlak, dan antonim yang bersifat relasi. Sebagaimana dalam kutipan berikut.

(8)" Saya jadi ingat perempuan-perempuan yang mengubah hidup saya. Saya jadi ingat pengemispengemis itu disimpulkan tangannya dibawah. Selalu disimpulkan di bawah, soalnya kalau tangannya di atas, itu konser. Konser sambil ngemis, minta mas minta mas. Saya itu memiliki kelembutan hati seperti ibu saya. Kalau saya melihat pengemis itu saya, dia tuh kasihan.”(III/1/AN/4)

Penanda "di bawah" dan "di atas" pada data (8) merupakan penggunaan penanda kepaduan sebuah kalimat berupa antonim yang bersifat relatif. Penanda " $d i$ bawah" pada data (8) dipakai oleh komika untuk menghubungkan kata atau frase dalam kalimat pengandaian pada kalimat "Selalu disimpulkan di bawah, soalnya kalau tangannya di atas, itu konser."

\section{Hiponim}

Hiponim ialah ungkapan yang maknanya dianggap merupakan bawahan dari makna kata atau ungkapan yang lebih tinggi. Penggunaan penanda kohesi antarkalimat yang berupa hiponim dalam penelitian ini ialah sebagaimana dalam kutipan berikut.

(9)" Cara makan saya pun berbeda dengan anak orang-orang desa. Orang-orang desa itu makanannya, biasanya saya makan itu table maner, peralatannya harus lengkap ada sendok, garpu."(VI/1/HP/7)

Penanda hiponim pada data (9) yaitu kata" sendok, garpu" dalam kalimat" Orang-orang desa itu makanannya, biasanya saya makan itu table maner, peralatannya harus lengkap ada sendok, garpu."kata "sendok" dan, kata "garpu" dalam kalimat tersebut berhiponim atau dapat dikatakan tercakup ke dalam makna kata "peralatan makan". Yakni makna kata yang lebih umum.

\section{Kolokasi}

Penggunaan penanda kohesi antarkalimat yang berupa kolokasi dalam penelitian ini adalah sebagaimana dalam kutipan berikut.

(10)" Saya guru, saya itu mengamati fashion murid-murid saya. Menurut saya kalau anak-anak itu dandanannya aneh-aneh itu tidak nakal, tetapi hanya cari perhatian pada lawan jenisnya. Ada rambutnya panjang terus dikepang, ada bajunya di keluarkan terus dikepang. Murid-murid itu tidak nakal hanya menarik perhatian saja. Harusnya waktu upacara bendera itu memakai sepatu hitam, tapi untuk menunjukan eksistensinya remaja itu ada yang menggunakan sepatu futsal biar kelihatan pemain futsal, pakai sepatu basket biar kelihatan pemain basket, ada yang gak pakai sepatu, kalau di tanya kamu anak pencak silat, kamu anak judo, maaf pak kemarin kebanjiran. Kenapa sih kayak rambut gondrong? menurut saya kalau anak-anak itu rambutnya gondrong itu selalu di potong gurunya biar rapi."(III/1/KL/310)

Dari data (10) diperoleh katakata "guru, murid", rambut panjang, "baju dikeluarkan", "upacara bendera", yang merupakan kata-kata dalam satu kolokasi, satu tempat, atau satu lingkungan. Dalam kalimat tersebut adalah sebagai subyek yang keberadaannya membutuhkan predikat, objek, dan keterangan untuk memperjelas kalimat tersebut.

\section{Sinonim}

Padanan kata atau sinonim, ialah ungkapan (bisa berupa kata, frase, atau kalimat) yang maknanya kurang lebih sama dengan ungkapan lain (Verhaar dalam Chaer, 1990:85).

Penggunaan penanda kohesi antarkalimat yang berupa padanan kata atau sinonim dalam penelitian ini sebagaimana kutipan berikut.

(11)" Saya guru, saya itu mengamati fashion murid-murid saya. Menurut saya kalau anak-anak itu dandanannya aneh-aneh itu tidak nakal, tetapi hanya cari perhatian pada lawan jenisnya. Ada 
rambutnya panjang terus dikepang, ada bajunya di keluarkan terus dikepang. Murid-murid itu tidak nakal hanya menarik perhatian saja. Harusnya waktu upacara bendera itu memakai sepatu hitam, tapi untuk menunjukan eksistensinya remaja itu ada yang menggunakan sepatu futsal biar kelihatan pemain futsal, pakai sepatu basket biar kelihatan pemain basket, ada yang gak pakai sepatu, kalau di tanya kamu anak pencak silat, kamu anak judo, maaf pak kemarin kebanjiran." (III/1/SI/3-10)

Penanda sinonim yang berupa kata "murid-murid" pada data (11) bersinonim dengan kalimat sesudahnya yaitu" anak-anak".

\section{Repetisi}

Repetisi merupakan pengulangan kata atau frasa yang sama pada kalimat berikutnya untuk memberikan penekanan bahwa kata atau frase tersebut merupakan fokus pembicaraan (Ghufron, 2015:175).

Penggunaan penanda kohesi antarkalimat yang berupa repetisi dalam penelitian ini sebagaimana kutipan berikut.

(12)" Selamat sore kawula muda, nama saya Dodit Mulyanto. Walaupun saya Jawa, keluarga saya itu memegang erat budaya Eropa makanya saya diajari main biola dari kecil."(I/1/RP/2)

Penanda "saya" pada data (12) dalam kalimat tersebut mengulang kata "saya" dengan kalimat berikutnya sebagai hubungan pertentangan untuk lebih memperjelas timbal balik kedua kalimat yang saling berkaitan.

\section{SIMPULAN}

Penanda yang dipakai untuk menunjukkan kekohesian dalam wacana tersebut antara lain penanda kohesi aspek gramatikal yang meliputi pronomina, substitusi, elipsis dan konjungsi.
Penanda kohesi aspek leksikal meliputi antonim, hiponim, kolokasi, sinonim, dan repetisi.

Penanda kohesi antarkalimat yang sering muncul sebagaimana pembahasan di atas yaitu pronomina dan konjungsi. Sedangkan penanda substitusi, elipsis, antonim, sinonim, dan repetisi jarang muncul dalam penelitian ini. Berdasarkan deskripsi tersebut penulis menyimpulkan bahwa penanda kohesi yang efektif membentuk wacana Stand up Comedy di KOMPAS TV adalah penanda pronomina dan konjungsi.

\section{DAFTAR PUSTAKA}

Alwi, Hasan dkk. 1998. Tata Bahasa Baku Bahasa Indonesia. Jakarta: Balai Pustaka.

Chaer, Abdul. 1990. Pengantar Semantik Bahasa Indonesia. Jakarta: Rineka Cipta.

Chaer, Abdul. 1994. Linguistik Umum. Jakarta: Rineka Cipta.

Gufron, Syamsul. 2015. Kesalahan Berbahasa, Teori dan Aplikasi. Yogyakarta: Ombak Dua.

Halliday, M.A.K dan Ruqaiya Hasan. 1979. Cohesion in English. Burnt Mill: Longman.

Kridalaksana, Harimurti. 1984. Pembentukan Kata dalam Bahasa Indonesia. Jakarta: PT Gramedia.

Sumarlam. 2003. Analisis Wacana. Teori dan Praktik. Surakarta: Pustaka Cakra. 